DOI: https://doi.org/10.36910/6775-2524-0560-2020-41-20

УДК: 004.65.012.45

Чернящук Наталія Леонідівна, д.п.н., професор

https://orcid.org/0000-0002-3178-8377

Бортник Катерина Яківна, к.т.н., доцент

http://orcid.org/0000-0001-5282-099X

Плевако Назар Миколайович, студент

Луцький національний технічний університет

\title{
АНАЛІЗ ДОСЛІДЖЕННЯ ФУНКЦІОНУВАННЯ ІНФОРМАЦІЙНОЇ СИСТЕМИ ЕЛЕКТРОННОГО ДОКУМЕНТООБІГУ
}

\begin{abstract}
Чернящук Н.Л., Бортник К.Я., Плевако Н.М. Аналіз дослідження функціонування інформаційної системи електронного документообігу. Розроблена програма надає можливість здійснення моніторингу успішності студентів. Проблеми прогнозування результатів сесії студентів у закладах вищої освіти в сучасних ринкових умовах $є$ актуальними 3 багатьх причин. По-перше, підготовка кваліфікованих фахівців - це одне з головних завдань будь-якої освітньої установи. По-друге, управління процесом навчення студентів в умовах впливу безлічі зовнішніх чинників $\epsilon$ складним завданням, як в організаційному, так і соціально-економічному плані, що вимагає системного підходу і розробки нових методів і моделей управління. Деканат бере участь в оперативному формуванні різних видів документів. Основними 3 них $є$ особисті справи студентів, дані про викладачів, заліково-екзаменаційні відомості, відомості результатів навчання студентів, зведені відомості, звіти за успішністю. Ці дані є вхідними для роботи системи. Звітні документи створюються за потребою на основі результатів навчання студентів та можуть відображати й особисту інформацію.
\end{abstract}

Ключові слова: дослідження, інформаційна система, деканат, успішність.

Чернящук Н.Л., Бортник К.Я., Плевако Н.М. Анализ исследования функционирования информационной системы электронного документооборота. Разработана программа предоставляет возможность осуществления мониторинга успеваемости студентов. Проблемы прогнозирования результатов сессии студентов в учреждениях высшего образования в современных рыночных условиях актуальны с багатьх причин. Во-первых, подготовка квалифицированных специалистов - это одна из главных задач любой образовательного учреждения. Во-вторых, управление процессом научения студентов в условиях воздействия множества внешних факторов является сложной задачей, как в организационном, так и социально-экономическом плане, что требует системного подхода и разработки новых методов и моделей управления. Деканат участвует в оперативном формировании различных видов документов. Основными из них являются личные дела студентов, данные о преподавателях, зачетно-экзаменационные ведомости, ведомости результатов обучения студентов, сводные ведомости, отчеты по успеваемости. Эти данные являются входными для работы системы. Отчетные документы создаются по необходимости на основе результатов обучения студентов и могут отражать и личную информацию.

Ключевые слова: исследование, информационная система, деканат, успешность.

Chernyashchuk N.L., Bortnyk K.Ya., Plevako N.M. Analysis of the study of the functioning of the information system of electronic document management. The developed program provides an opportunity to monitor student performance. Problems of forecasting the results of student sessions in higher education institutions in today's market conditions are relevant for many reasons. First, the training of qualified specialists is one of the main tasks of any educational institution. Second, managing the learning process of students under the influence of many external factors is a difficult task, both organizationally and socio-economically, which requires a systematic approach and the development of new management methods and models. The Dean's Office participates in the operational formation of various types of documents. The main ones are personal files of students, data on teachers, test and examination information, information on student learning outcomes, summary information, performance reports. This data is the input for the operation of the system. Reporting documents are created as needed based on student learning outcomes and can reflect personal information.

Key words: research, information system, dean's office, success.

Постановка наукової проблеми. Інформаційна система - це взаємопов’язаний набір даних, обладнання, програмного забезпечення, персоналу, стандартних процедур збору, обробки, розповсюдження, зберігання та подання інформації відповідно до вимог, що випливають із цілей організації. Сьогодні, в епоху інформації, майже кожна інформаційна система використовує комп'ютерні технології, а отже, в майбутньому, в рамках інформаційних систем, ми будемо автоматизовані. Інформаційні системи включають: обладнання для обробки даних, програмне забезпечення та відповідний персонал. Чотири складові частини становлять внутрішню інформаційну основу: • засоби запису та збору інформації; • засоби передачі відповідних даних та повідомлень; • засоби зберігання інформації; - інструменти для аналізу, обробки та подання інформації. Тому проблема виникає при розробці інформаційних систем безпосередньо у вищому навчальному закладі, точніше, вони відповідають його конкретним умовам та вимогам, оскільки розробляються у тісному контакті з майбутніми користувачами та зручні для використання персоналом навчального заклад. Але в системах комерційного розвитку, часто для того, щоб отримати кінцевий продукт - звітний документ або масив інформації для аналізу - користувачеві необхідно виконати додаткову конфігурацію параметрів, використовуючи різні генератори звітів та форми налаштування, вимагає від нього 
додаткових навичок не характерні для його професійної діяльності або такого ж залучення фахівців, компетентних у галузі програмування та комп’ютерних технологій. У самостійно розроблених системах такі проблеми нівелюються тим, що програмісти вирішують їх на етапі розробки продукту, надаючи користувачам інструмент, максимально адаптований до їх професійних вимог.

\section{Аналіз досліджень.}

У цьому контексті інформацію про системи, автоматизацію та монопольне управління внутрішньою іпотекою, дослідження проблем, доповнення процесів управління в Україні було представлено Ю.І. Бєляєв, О. В. Співаковський, Д.Є. Щедролосєв (Херсонський державний університет), О. Ю. Чередніченко (Національний технічний університет "Харківський політехнічний інститут"), В. Ю. Біков (Інститут інформаційних технологій та України), В.П. ), Б. І. Мокін та В.Б. Мокін (Вінницький національний технічний університет), Є. Ю. Катаєва, Є. В. Ланського (Черкаський державний технологічний університет) та інші $[1 ; 3]$. У той же час в середині наукових матеріалів не часто можуть бути відомі аналітичні установки та уявлення про функціональні можливості певних систем. Віше, інформація про системи, зміни в позитивній i негативній сторонах, а також розпізнавання аналізів на основі результатів аналізу. Ца robitsya по застосуванню dvoh informatsiynih систем kompleksnoї avtomatizovanoї SISTEMI upravlinnya Навчального процесу з umovnoyu NAME "Дін" і stvorenoї vprovadzhenoї в ekspluatatsiyu в Львівському instituta institut isinivskoїvinsesta institutivskoïnivskoïnivskoïvskoïvskoïvivskoïvivskoïnivskoïvinstitutiï Politek-SOFT», як такоже ekspluatuctsya на tsomu instituti [2;5].

\section{Виклад основного матеріалу.}

Якісні показники і зручність експлуатації різноманітних систем автоматизації управління навчальним процесом у навчальних закладах не однакові, вони значно коливаються залежно від досвіду розробників та поставлених перед ними технічних вимог, проте спостерігаються певні тенденції, типові недоліки та позитивні ознаки, притаманні подібним інформаційним системам.

Без застосування ЕОМ або графічні методи дають змогу відобразити: організаційні, функціональні, виробничі та загальноекономічні характеристики об'єкта, який вивчаємо, i їх взаємозв'язки, послідовність впливу окремих факторів, порядок формування як первинних, так i результатних показників [9; 3].

Для того щоб показати складний, багатоступеневий зв'язок у досліджуваних об'єктах, процесах і явищах, застосовують таблиці, графіки, діаграми і структурні схеми для аналізу динаміки якогонебудь процесу (випуск продукції за кілька років, аналіз трудових ресурсів і т.п.).

Головна вимога - компактний, логічно побудований запис чи відображення у вигляді символів, який дає змогу легко вносити зміни і доповнення в розглядуваний процес, можливості використання прийнятої термінології (символіки) та інших умовних позначень для скорочення текстових нотаток.

Залежно від цілей i задач дослідження потоки інформації можна вивчати, описувати i аналізувати на макро- чи мікрорівні. На макрорівні аналізують загальну структуру і схеми функціонування інформаційної системи, вдосконалюють документопотік [10; 12].

Табличне зображення дає змогу судити про рух документів між окремими підрозділами об’єкта, виконавцями. По вертикалі записують роботи чи функції, по горизонталі - організовують структуру об'єкта. Документи позначають прямокутниками, а їх - рух лініями. На базі таблиць будують схеми руху документів, виявляють методи обробки і заповнення документів. Для більш поглибленого аналізу періодичності формування документів і отримання об'ємних характеристик складають карту обстеження документопотоків. У ній можна наводити: код і найменування підрозділу, код i найменування документа, номер затвердженої форми, код підрозділів по маршруту документа, код періоду складання, код вихідних документів, код і найменування задачі, об'ємні характеристики (кількість рядків, знаків). Недолік - відсутність наглядності через статичність відображуваних у картах інформаційних сукупностей. При побудові оперограм увесь процес обробки інформації поділяють на елементарні операції, які розглядають як найменшу логічно закінчену частину всього комплексу досліджуваного процесу. Кожну елементарну операцію, носій інформації і т.п. відображають на оперограмі у вигляді умовного запису. У середині можна записувати номер документа та інші пояснення (рис. 1). 


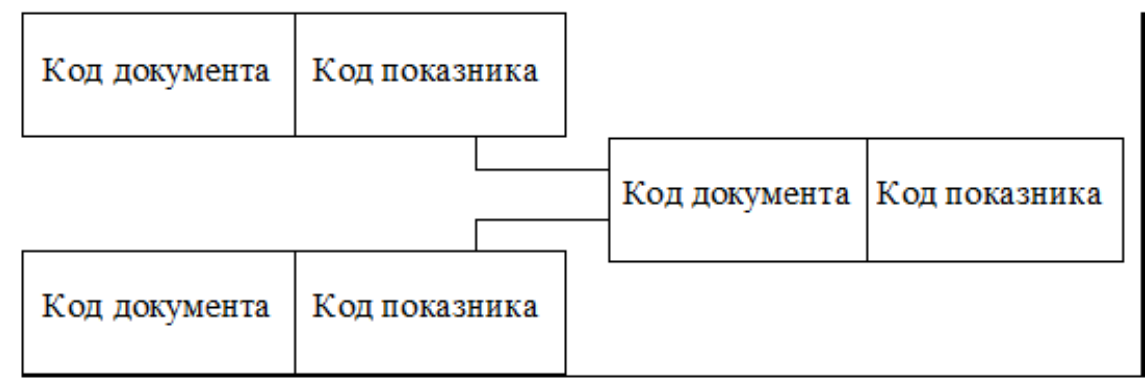

Рис. 1 Фрагмент оперо грами

Переваги: наочність відображення не втрачає, якщо шлях документа складний; досліджується не лише порядок руху документів, а й засоби обробки змісту в них даних, можуть вноситися також рекомендації щодо їх вдосконалення.

Структурні схеми інформаційного складу функцій і процесів відбивають взаємозв'язок процесів, вхідну і вихідну інформацію, яка використовується, джерела інформації та ін. (рис. 2).

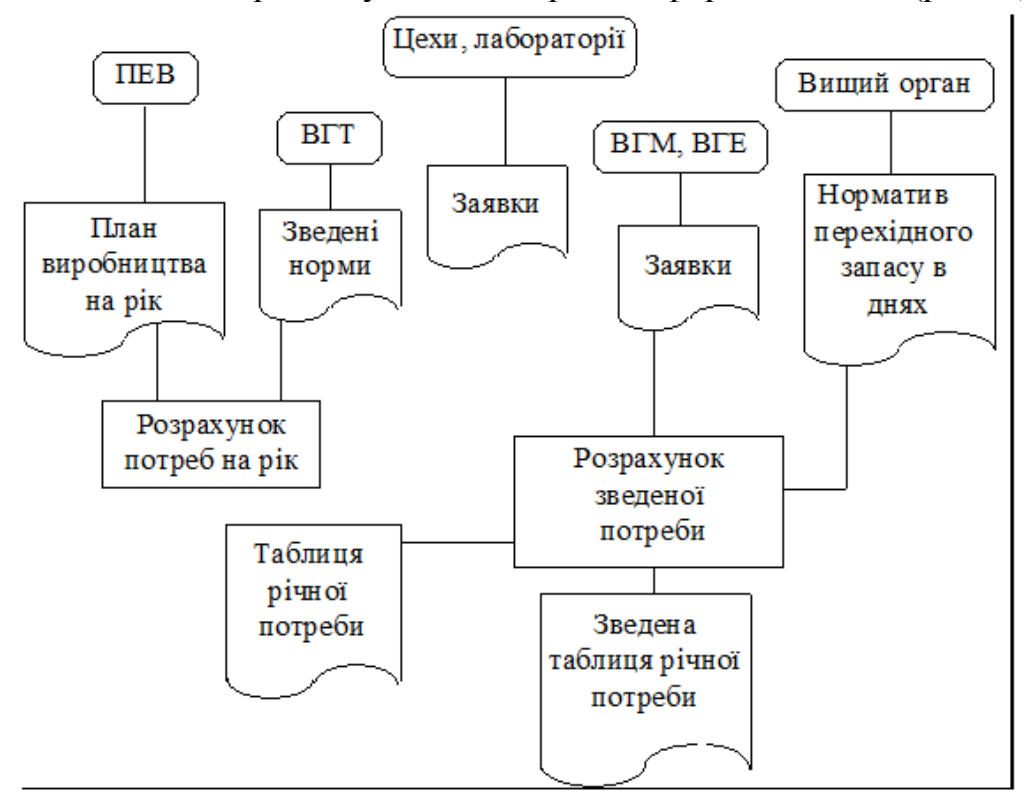

Рис. 2 Структурна схема розрахунку зведеної потреби в матеріалах на рік

Побудова таких схем полегшить перехід до процесу проектування, оскільки видно логічну послідовність виконання операцій і можливість зміни порядку обробки даних, суміщення окремих операцій, раціональної побудови вихідної інформації і т.п.

Для детального аналізу інформаційної системи документопотоки аналізують іще на мікрорівні. Досліджують зміст інформаційних носіїв, аналізують інформаційні сукупності, показники, атрибути (реквізити). Найбільшого поширення набуло табличне зображення показників, що аналізуються, «Карта обстеження інформаційних потоків за показниками», яка містить код підрозділу, код документа, найменування показника, код показника, джерело формування показників (номер документа, номер показника, найменування показника, код показника, алгоритм формування показника) [4; 8].

Графічний метод застосовують для опису потоків невеликої розмірності. Головний елемент документа $-D j(j=1,2, \ldots, m)$, компоненти документа $-K$, набір компонентів - $D j k$. Інформаційна множина - це найменування, які збігаються за змістом окремих компонентів, що входять до складу всіх документів досліджуваної інформаційної системи. Однак при збільшенні розмірностей потоку трудомісткість і складність використання цього методу різко зростають, а це обмежує практичне застосування.

Інформація про діючу систему управління деталізується і уточнюється в міру заповнення документації. Якщо виконують які-небудь розбіжності за одними і тими самими показниками, потрібно провести додаткове дослідження для виявлення достовірної інформації. Вся інформація, отримана при вивченні діючої системи, міститься в розглянутій документації, сукупність якої $€$ формалізованим описом моделі діючої системи. 
Основою створення інформаційної системи є модель системи управління, яка відбиває склад об’єкта, характер взаємодії його елементів і їх особливості. На цій стадії головна мета обстеження отримання необхідних відомостей і побудова моделі системи управління. Ця модель повинна відбивати всі функції об’єкта, показники, які при цьому використовуються, схеми, процедури, їх рух і розробку [7; 5]. Вона може мати вигляд інформаційної схеми, яка містить близько 4 тис. показників, пов'язаних між собою відповідними процедурами обробки. Наявність повної робочої моделі на перших етапах створення інформаційної системи не $\epsilon$ необхідною умовою. На першому етапі створюється концептуальна (принципова) модель системи управління як методичної основи створення інформаційної системи. На другому - здійснюється розробка детального обмеженого першочергового переліку функцій управління або комплексу моделей управління діяльністю об'єкта [3; 11].

Так, на схемі даних показано шлях даних при розв'язанні задач і визначено етапи обробки, а також різні носії даних, які застосовуються (рис 3).

Модель проблемної сфери - це параметричне формалізоване зображення процесу циркуляції і обробки інформації в системі виробництва і управління, яка відбиває дійсність у спрощеному вигляді.

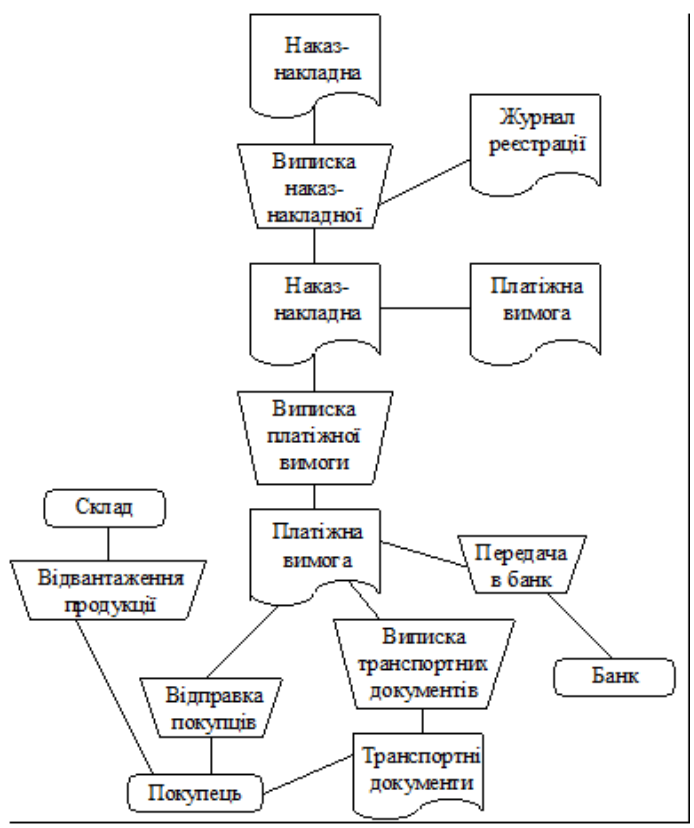

Рис. 3. Схема даних з обліку відвантаження готової продукції у відділі збуту

Отже, при проектуванні інформаційної системи застосовують методи з використанням ЕММ і EOM: сіткову модель, матричну модель, графоаналітичний метод, опис процедур на алгоритмічній мові, динамічну інформаційну модель.

Сіткова модель відбиває взаємозв'язки функцій і процесів правління, вона будується за окремими функціями управління, підрозділах і об'єкта в цілому. Під подією розуміють певний документ, який містить результат конкретного процесу, під роботою - виконання працівниками управління логічних, арифметичних та інших операцій з формування документа, який розглядається. Вона дає змогу здійснювати комплексний аналіз функцій управління, виявляти вузькі місця, аналізувати тенденцію розвитку потоків інформації, прогнозувати функціонування всієї системи. Проте ця модель не дозволяє виявити зміст повідомлень, які передаються, і неповно характеризує складний документообіг [8; 9].

Матрична інформаційна модель $\epsilon$ шахова таблиця, в якій записують у рядках і стовпцях документи і показники, а на перетині відмічають їх взаємозв'язки у системі управління, що дає змогу визначити, скільки разів і для створення яких показників використовується кожний із них. У таблиці виділяють чотири квадранти. У першому квадранті підсумок по кожному стовпцю показує, скільки показників використовується для формування показника, записаного у даному стовпці, а підсумок по рядку - скільки разів показник даного рядка використовується при створенні інших показників. Перший i третій квадранти дають уявлення про застосування кожного із показників, другий $\mathrm{i}$ четвертий - виявляють осідання показників, перелік показників, які надійшли, знову розраховані й не використовуються у подальшій роботі [7; 12]. 
За допомогою матричних моделей можна раціоналізувати документопотік, виявити дублювання в документах і показниках, встановити надмірні показники і документи, виявити показники, яких не вистачає. Недоліки: не дають уявлення про детальну постановку задач $з$ метою їх алгоритмізації, неповно відбивають динаміку інформаційних потоків, не відображають технології обробки документів.

Графоаналітичний метод передбачає відображення потоків інформації у вигляді орієнтованого графа, вершини якого відбивають певні структурні одиниці (підрозділи об’єкта), а ребра інформаційні потоки і засоби передавання. Опис потоків інформації зводиться до заповнення уніфікованої таблиці закодованими даними на спеціальній мові. Обробка таблиць виконується на EOM. За допомогою цього методу можна виявити у потоках інформації ту, що дублюється, встановити динамічні характеристики інформаційних потоків (обсяг даних по кожному документу, методику його формування і т.п.) [4; 9].

Опис процедур на алгоритмічній мові дає змогу схарактеризувати процес обробки інформації, який аналізується, і розробити програми автоматизації процесу руху інформаційних потоків, їх удосконалення, інтеграції і т.п. Цей метод в основному використовується спільно з іншими методами. Однак для цих методів характерні значні обсяги ручних робіт і фрагментарне використання ЕОМ на стадії обробки даних, обстеження і моделювання процесів, які вивчаються. Як правило, вони фіксують стан системи на конкретний момент часу, на момент обстеження, що не дає змоги взяти до уваги ті зміни, які відбулися після обстеження [5; 11].

Динамічна інформаційна модель будується як інформаційно-довідкова система i може застосовуватись для спостерігання за станом системи управління у режимі функціонування об' єкта.

Інформаційне забезпечення моделі складається з трьох базисних масивів.

1. Інформація про структуру управління дає змогу отримати кількісні характеристики в різних розрізах.

2. Дані про існуючі потоки інформації.

3. Дані про кожний документ, включаючи опис атрибутів.

Усі дані постійно оновлюються і віддзеркалюють реальний стан об'єкта. Модель надає таку інформацію: про структуру і кількісні характеристики підрозділів об'єкта; про інформаційні та управлінські зв'язки підрозділу з іншими об'єктами і елементами системи; про маршрути руху документів; про технологію формування документів; про застосування документів і реквізитів; періодичність їх складання і т. ін [10;3].

Динамічну модель розглядають не лише як інструмент для передпроектного аналізу системи, але і як основу створюваної інформаційної системи, як динамічну стежучу за допомогою ЕОМ систему, котра може інформаційно відображати в кожний момент часу стан усіх підрозділів об'єкта і всіх його елементів у період функціонування. Із упровадженням інформаційної технології дані стають своєрідним ресурсом економічного об'єкта. Так, набули широкого розвитку бази даних і знань під керуванням своєї СУБД. На цьому етапі виникла потреба створити словники-довідники даних (ССД) іще на етапі дослідження об'єкта. Вони суттєво змінюють методи проектування. Так, ручне проектування необхідне лише для оновлення даних, які зберігаються [12;3].

Дані в словниках-довідниках описують один раз, надалі ж, описуючи звіти, файли, програми, тільки посилаються на визначення, які вже є. Словник-довідник може формуватися вручну групою розробників інформаційної системи, яка створює формалізований опис даних і підтримує їх каталоги. Однак у цьому разі ускладнюється контроль за внесенням змін. Уникнути цих складнощів допомагають програмні системи ведення словників-довідників даних чи СУБД СДД.

ССД $є$ динамічною інформаційною моделлю проекта інформаційної системи, яка супроводжує його протягом усього життєвого циклу. У ССД описують усі інформаційні побудови, що присутні в проекті, об'єкти, які їх використовують, а також взаємозв'язки між ними. У ССД може зберігатися інформація про атрибути, показники, бази даних, вхідні й вихідні повідомлення, записи, файли, програмні модулі, пакети прикладних програм, обладнання введення-виведення, документи проекту і т.п.

Первісне завантаження інформації у ССД виконується на першій стадії. На наступних стадіях життєвого циклу ССД безперервно модифікується і доповнюється, зберігаючи повну відповідність проекту, забезпечуючи його інформаційну єдність [5; 9].

ССД є основою автоматизації документування проекту інфор-маційної системи. Сам проект може містити в середньому щонайменше 4000 показників, одну базу даних, близько 200 форм вхідних і 400 форм вихідних повідомлень, порядку 400 файлів, приблизно 1000 програм, 6 ППП, 20 обладнань введення-виведення, 69 документів проекту. 
Без СУБД ССД його створення і функціонування має теоретичну абстракцію. При СУБД ССД його організація і ведення зводяться до таких операцій: внесення нових компонентів і їх зв'язків; коригування компонентів і зв'язків; пошук інформації, причому вхід може бути з будь-якої із зазначених складових: виведення на друк чи на екран дисплея інформації про компоненти і зв'язки; контроль даних, наприклад виконання накладених заборон $[6 ; 12]$.

У результаті проведення всіх вказаних робіт з`являються:

- доцільність і можливість створення IC на даному економічному об`єкті;

- тип створюваної IC (інформаційно-довідкова, інформаційно-порадницька, експертна та інші системи);

- формування загальної економіко-математичної моделі управління об єктом в умовах IC;

- визначення бажаних характеристик IC і приведення техніко-економічного обгрунтування цих характеристик.

Постановка задачі інформаційної системи - необхідна та достатня сукупність знань 3 конкретної задачі інформаційної системи, які визначають їі суть, вимоги до регламенту рішення, вхідних даних і конкретних результатів.

Склад: характеристики комплексу задач; вихідна інформація; вхідна інформація; може містити опис алгоритму (дублювання змісту розділів об'єднаного документа не допускається).

1. Характеристики комплексу задач:

- призначення комплексу задач;

- перелік об'єктів (технологічних об'єктів управління, підрозділів підприємств і т.п.), при управлінні якими розв'язують комплекс задач;

- періодичність і довготривалість розв'язання;

- умови, за яких припиняється розв'язання комплексу задач автоматизованим способом (у разі потреби).

- зв'язок даного комплексу з іншими комплексами можемо показати на інформаційній моделі (рис. 4):

- посади осіб і (чи) найменування підрозділів, які визначають умови і часові характеристики конкретного розв'язання задачі;

- розподіл дій між персоналом і технічними засобами в різних ситуаціях розв'язання комплексу задач.

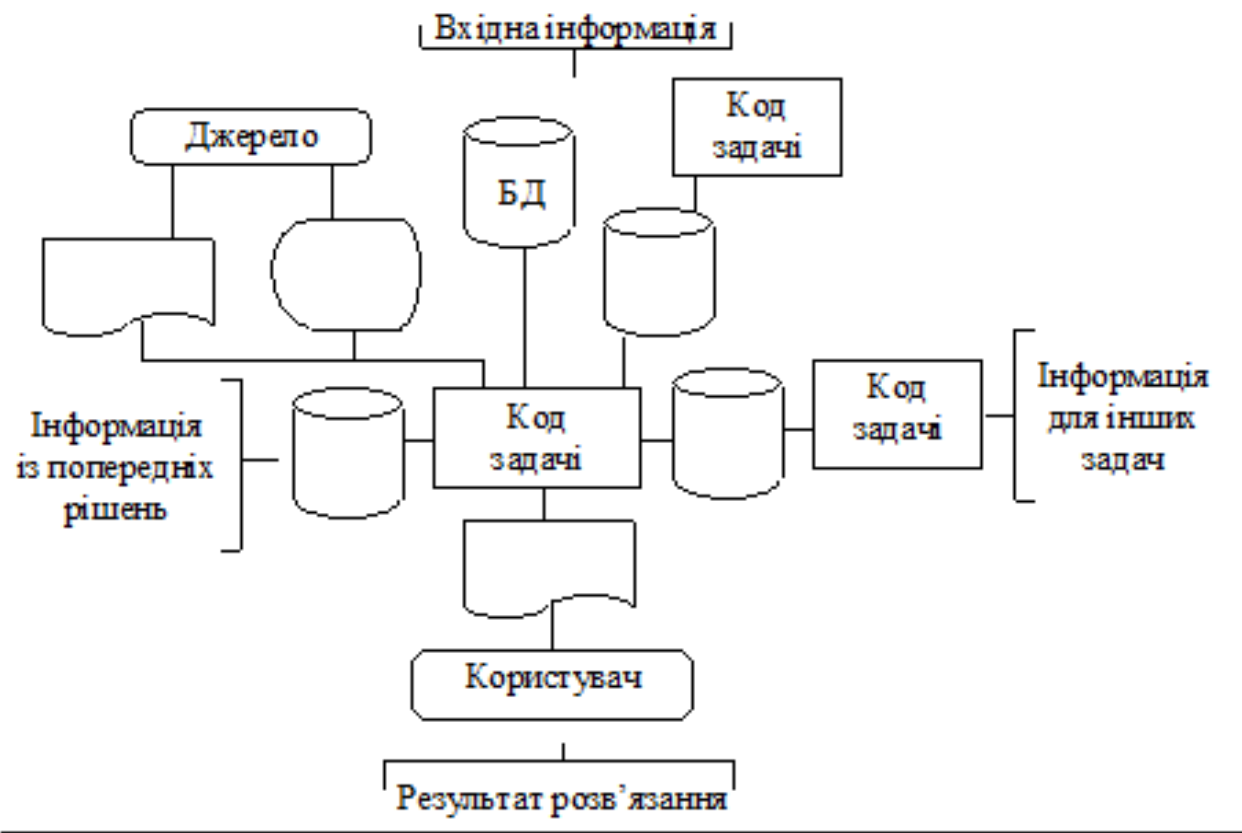

Рис. 4. Функціональна схема роботи об'єкта проектування 
На сьогоднішній день достатньо актуальним є питання автоматизації навчального процесу, зокрема, автоматизації процесів управління у вищих навчальних закладах (3ВО).

Мета автоматизації управління - отримати зручні засоби моніторингу, аналізу та відображення основних процесів прийому студентів, адміністративного управління, підготовки та випуску фахівців університету (інституту, академіï) [1].

Слід зазначити, що одній з основних та трудомістких в роботі ЗВО є діяльність деканату, а саме процес контролю та аналізу успішності студентів. Працівникам деканатів доводиться виконувати величезний обсяг рутинної роботи 3 обліку контингенту студентів, забезпечення навчального процесу, наданню інформації в різні підрозділи ЗВО, формування звітності за результатами навчання студентів. При цьому, всю інформацію необхідно надавати в різних форматах та здійснювати прогноз успішності студентів з метою ефективного контролю за процесом навчання та своєчасного реагування на можливі негативні результати (пропуски занять, низькі показники абсолютної та якісної успішності, тощо) [2].

Таким чином, необхідність впровадження інформаційної системи (IC), що автоматизує основні функції освітнього процесу є актуальною задачею.

Основними завданнями, що відображені у даному матеріалі, $\epsilon$ опис етапів проектування інформаційної системи «Деканат» та аналіз особливостей реалізації даної системи на базі платформи 1С:Підприємство. 1. Концептуальна модель бази даних.

Деканат бере участь в оперативному формуванні різних видів документів. Основними з них є особисті справи студентів, дані про викладачів, заліково-екзаменаційні відомості (за предметами), відомості результатів навчання студентів, зведені відомості, звіти за успішністю. Особиста справа складається на окремого студента.

Вона містить основні відомості про студента з його особистої картки. Ці дані є вхідними для роботи системи. Звітні документи створюються за потребою на основі результатів навчання студентів та можуть відображати й особисту інформацію.

Для кожного предмета в період сесії формується заліково-екзаменаційна відомість, де викладач заносить результати навчання за своєю дисципліною. За цими відомостями формуються звіти для кожного студента, які заносяться до особистої справи. Одним з основних звітних документів, які відображають результати успішності всіх студентів факультету, $\epsilon$ зведена відомість, яка складається за всіма студентами та дисциплінами. Вона містить такі основні дані: ПІП, курс, факультет, форма навчання, назва предметів, оцінки. Але цієї відомості недостатньо для повного аналізу та короля якості навчання. За цими відомостями формується такий документ, як «Форма 10», де відображається абсолютна та якісна успішність студентів, та за потребою формується ще низка звітів (будуються рейтинги, діаграми, тощо), які охоплюються статистичні дані, що відображають загальні характеристики навчального процесу. Для створення бази даних (БД) необхідно розглянути процеси документообігу в деканаті. Структура цих процесів представлена на рис. 5. Ці структури побудовані за допомогою середовища BPwin, Erwin, Rational Rose.

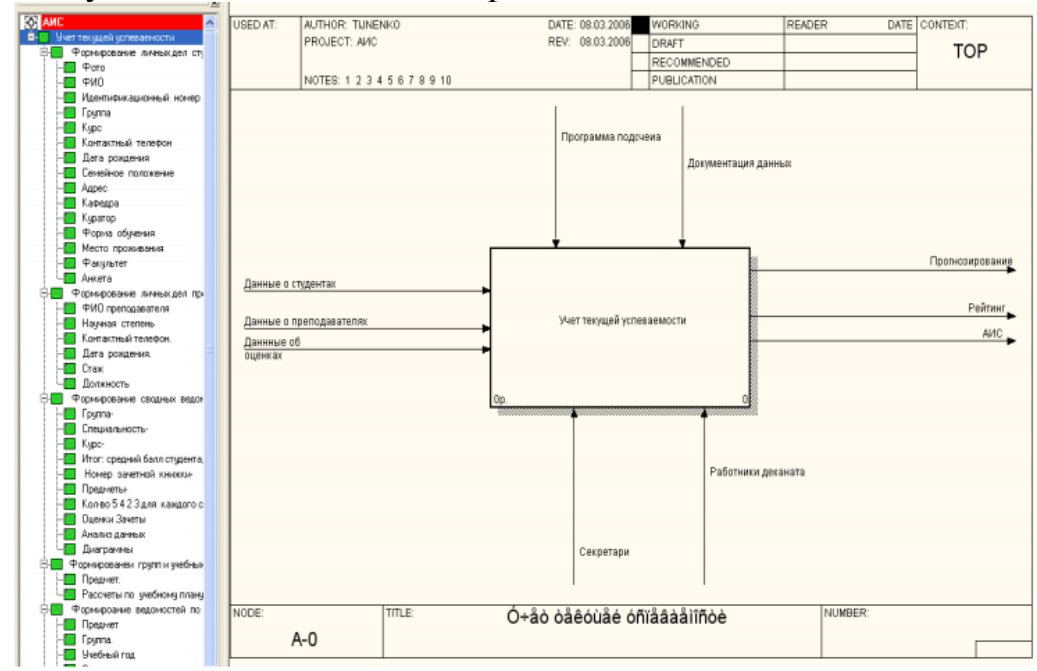

Рис. 5 Контекстна діаграма інформаційної системи в середовище BPwin 


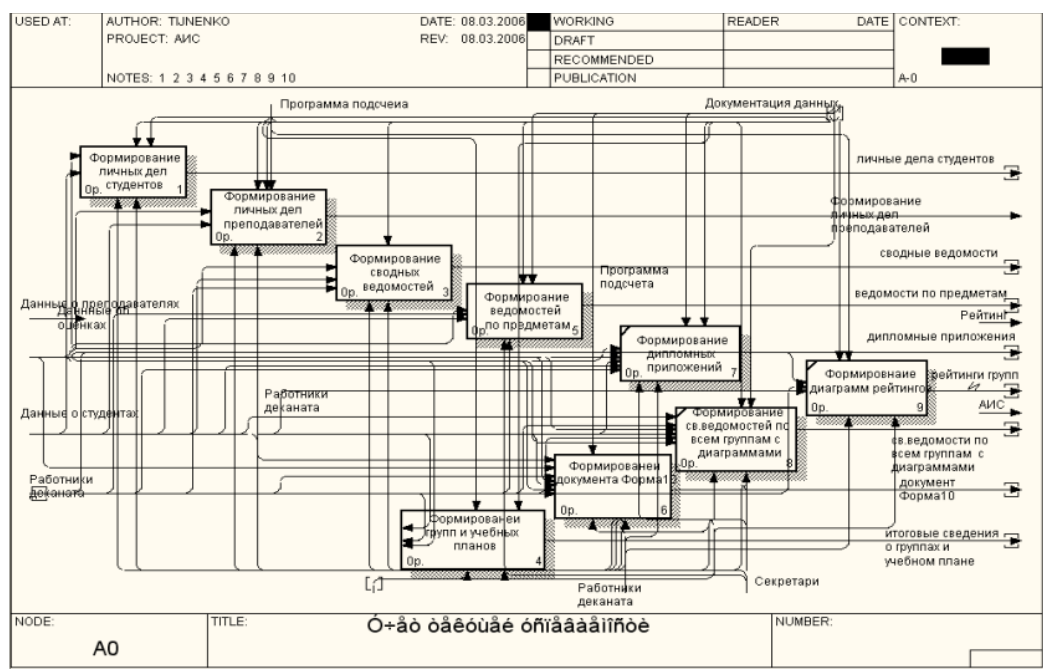

Рис. 6 Діаграма декомпозицій інформаційної системи в середовище BPwin

Так як всі дані, що надходять в деканат (вхідна документація), відображаються в різних звітах - зведеній відомості, відомостях за предметами, за студентами, то дані можуть заноситися до бази даних шляхом «Введення на підставі», що дає можливість позбавитися дублювання інформації.

Цей механізм добре реалізований в системі конфігурування 1С:Підприємство [4;5].

Потім можна скласти стандартний набір запитів для спрощення вибірки даних та на основі складених запитів згенерувати звіти, які б виводили необхідну інформацію.

Очевидно, що ці звіти можна роздрукувати i таким чином отримати готові звітні документи.

Конфігуратор 1C також надає можливість швидкого налаштування форм звітності та зміну даних виводу [5].

На основі структури процесу документообігу в деканаті були виділені основна сутності та атрибути предметної області, встановлені зв'язки між об'єктами та розроблена логічна та фізична моделі БД.

На рис. 7 наведена логічна модель БД, яка відображає основні сутності, їх атрибути та зв'язки між сутностями.

В процесі розробки структури БД було використано технологію типового проектування та семантичного моделювання [6;7], що дозволило досить повно описати предметну область деканату та врахувати множину даних, які є важливими в процесі управління якістю навчальним процесом.

На рис. 6 подана діаграма прецедентів, що відображає документообіг в деканаті. Схема формування документів в $1 \mathrm{C}$ представлена на рис. 8 .

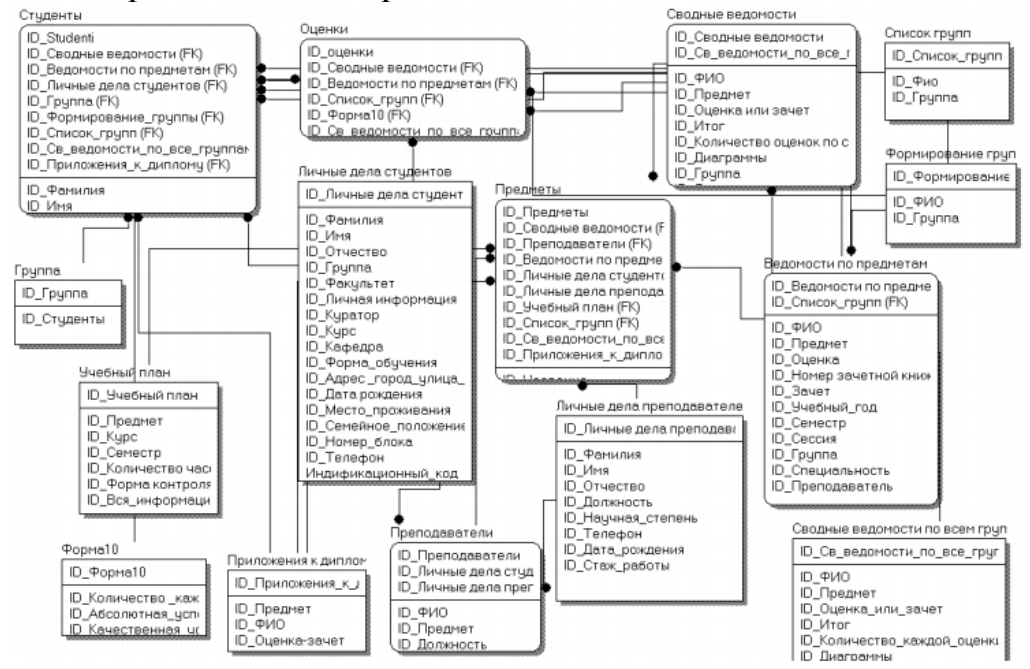

Рис. 7. Логічна модель БД 


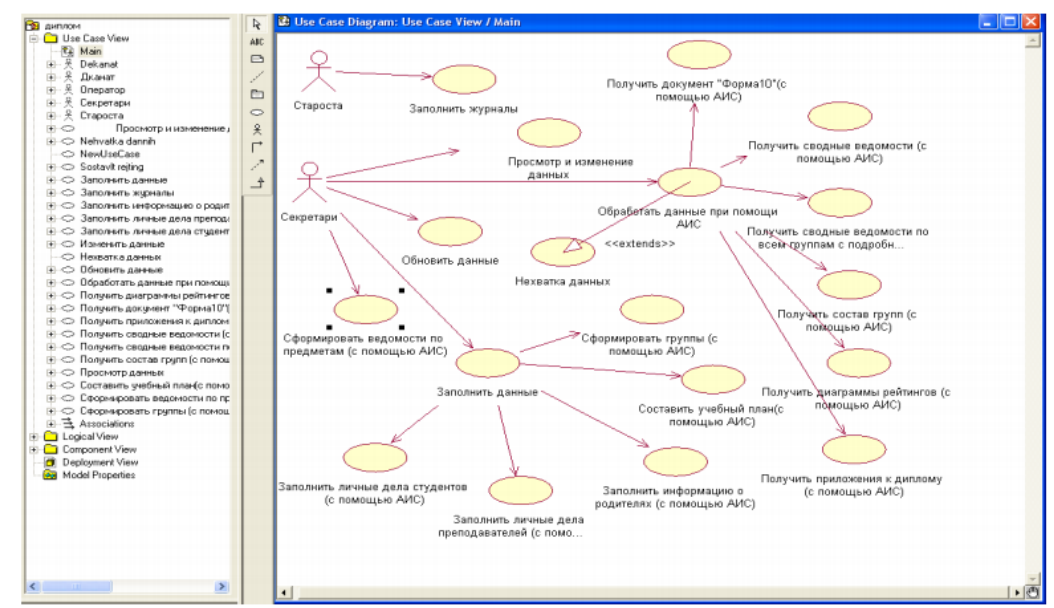

Pис. 8. Подання документообігу в середовище Rational Rose (діаграма прецедентів)

Вибір програмного інструментарію. Для розробки комп'ютерної системи контролю та аналізу успішності студентів був вибраний програмний інструментарій - платформа конфігурування 1С:Підприємство [4; 5]. 1С:Підприємство $є$ універсальною системою автоматизації економічної і організаційної діяльності підприємства.

Оскільки така діяльність може бути різноманітною, система 1C:Підприємство може «пристосовуватися» до особливостей конкретної області діяльності, в якій вона застосовується.

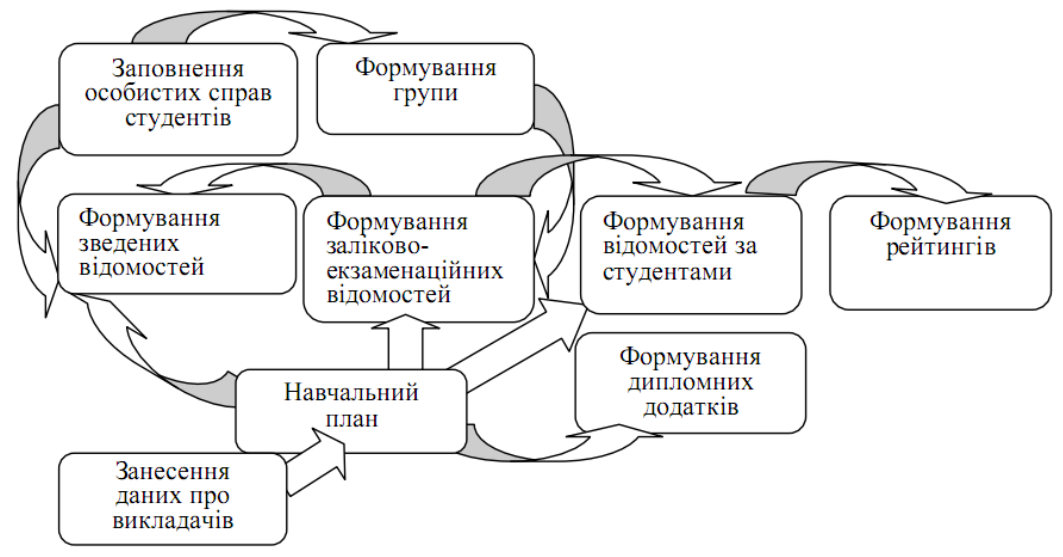

Рис. 9. Схема формування документів у системі 1C

Для позначення такої здатності використовується термін конфігурується, тобто $є$ можливість настройки системи на особливості конкретного підприємства і класу вирішуваних завдань. Логічно всю систему можна розділити на дві великі частини, які тісно взаємодіють одна 3 однією:

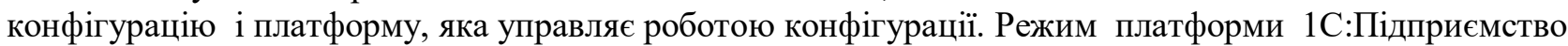
$\epsilon$ основним і служить для роботи користувачів системи. У цьому режимі користувачі вносять дані, обробляють їх і отримують вихідні результати.

Режим конфігуратор використовується розробниками і адміністраторами інформаційних баз. Саме цей режим і надає інструменти, необхідні для модифікації тієї, що існує або створення нової конфігурації.

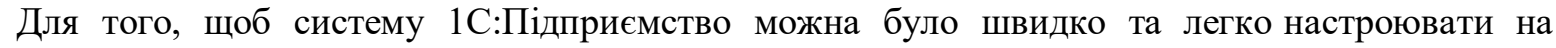
потрібні прикладні завдання, весь опис, який містить конфігурація, складається 3 логічних одиниць, званих об'єктами конфігурації. Алгоритми обробки й аналізу даних здійснюються 3 використанням вбудованої метамови. Все це обумовлюе вибір 1С для розробки інформаційної системи «Деканат» для вищих навчальних закладів України. Використання цієї системи є незвичним для вирішення завдань контролю та аналізу успішності студентів ЗВО. 3. Фізична реалізація IC «Деканат».

IC «Деканат» була реалізована у вигляді кінцевого програмного продукту. Були розроблені наступні об'єкти, які можна розділити на три групи: «Довідники», «Документи», «Звіти», «Регістри відомостей» (рис. 9). На основі структури БД були сформовані наступні довідники: «Особисті справи студентів», «Особисті справи викладачів», «Факультети», «Відомості за студентами», 
«Інформація про сім'ю», «Предмети», «Групи», «Спеціальності», «Навчальний рік»; документи: «Учбовий план», «Формування групи», «Відомості за предметами», звіти: «Звідні відомості», «Списки груп», «Рейтинг груп за предметами», «Додатки до диплому», «Звідні відомості за всіма групами 3 діаграмами»; регістри відомостей: «Склад групи», «Навчальний план», «Оцінки». На рис. 10. відображено головне меню системи.

На рис. 11 надана форма «Зведена відомість», де відображено не тільки результати навчання студентів, але і статистичні дані, що дозволяють проводити всебічний аналіз. На рис. 12 представлено результати формування «Форми 10». Побудовані рейтинги успішності студентів, сформовані звітні документи та здійснено аналіз даних за результатами весняної сесії.

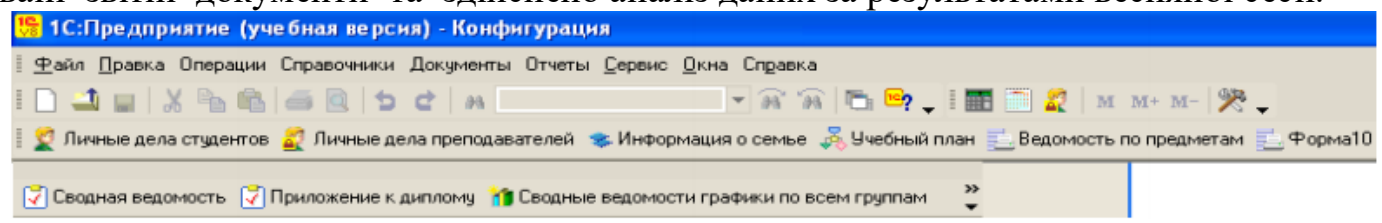

Рис. 10. Меню IC «Деканат»

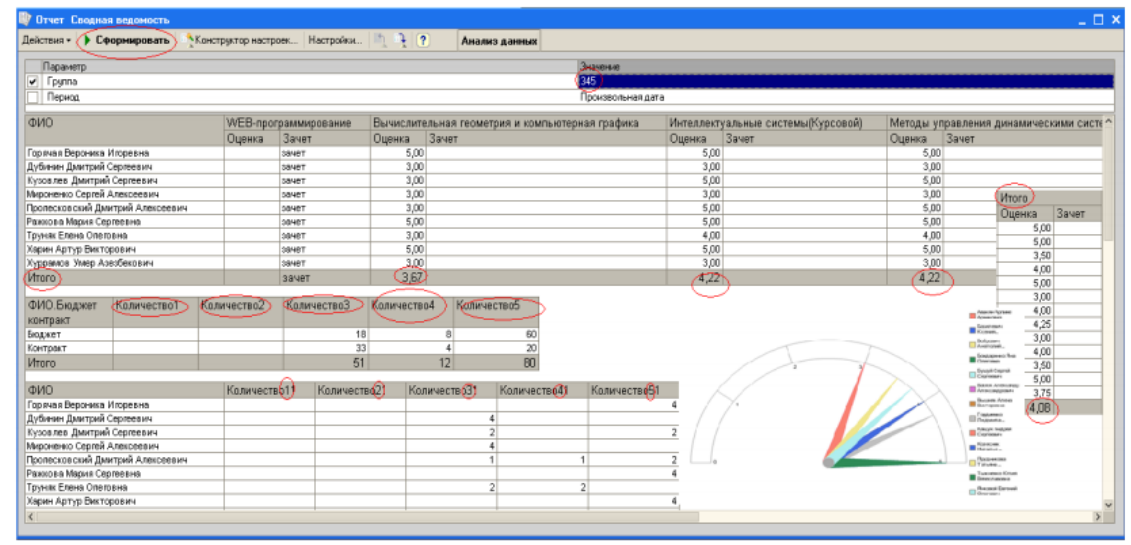

Рис. 11. Зведена відомість з результатами статистичного аналізу даних

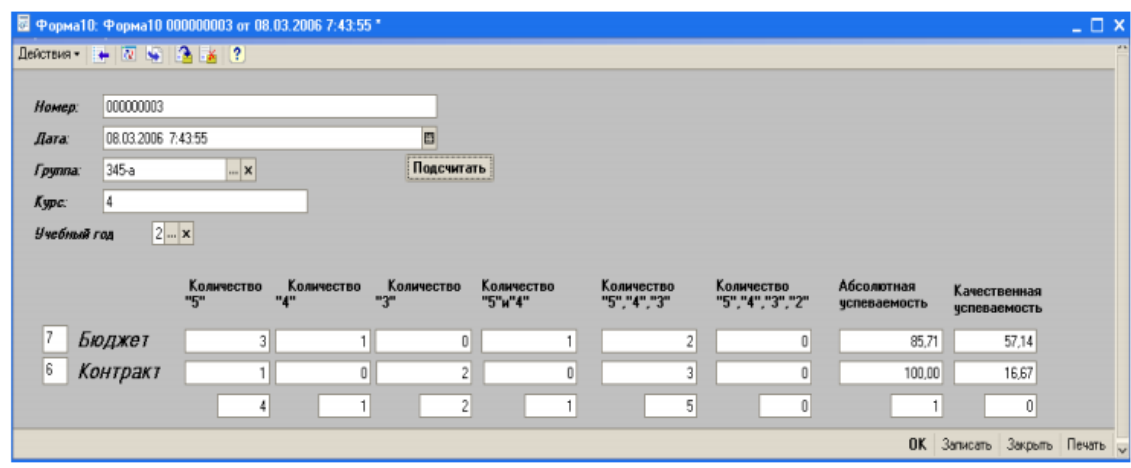

Рис. 12. Формування звітного документу «Форма 10»

\section{Висновок.}

Таким чином, в роботі представлено основні етапи проектування інформаційної системи контролю та аналізу успішності студентів ЗВО. Запропонована IC «Деканат» на базі платформи 1C:Підприємство призначена для ведення документообігу в деканаті, формування звітних документів, контролю та аналізу якості навчання. Обраний програмний інструментарій дозволяє оперативно та якісно отримувати необхідні звіти та аналізувати показники навчального процесу.

Список бібліографічного опису.

1. Анісімов А.В. Інформаційні системи та бази даних: Навчальний посібник для студентів факультету комп’ютерних наук та кібернетики. / Анісімов А.В., Кулябко П.П. - Київ. - 2017. - 110 с.

2. Антоненко В. М. Сучасні інформаційні системи і технології: управління знаннями : навч. посібник / В. М. Антоненко, С. Д. Мамченко, Ю. В. Рогушина. - Ірпінь : Нац. університет ДПС України, 2016. - 212 с.

3. Інформаційні системи в промисловості : навчальний посібник / Л. О. Добровольська, О.О.Черевко. - Маріуполь : ПДТУ, 2014. - 238 c.

4. Калінеску Т.В. Інформаційні системи і технології в оподаткуванні: навч. посіб. / Т.В. Калінеску, Г.С. Ліхоносова, О.М. Антіпов. - Луганськ: вид-во СНУ ім. В. Даля, 2011. - 407 с. 
5. Клімушин П. С. Інформаційні системи та технології в економіці : навч. посіб. / П. С.Клімушин, О.В. Орлов, А.О. Серенок. - Х. : Вид-во ХарРІ НАДУ «Магістр», 2011. - 448 с.

6. Костріков С. В. Географічні інформаційні системи: навчально-методичний посібник. / Костріков С. В., Сегіда К. Ю. - Харків, 2016 - 82 с.

7. Морзе Н.В. Інформаційні системи. Навч. посібн. /за наук. ред. Н. В. Морзе; Морзе Н.В., Піх О.3. - ІваноФранківськ, «ЛілеяНВ», - 2015. - 384 с.

8. Павлиш В. А. Основи інформаційних технологій і систем: Навчальний посібник. / Павлиш В. А., Гліненко Л. К. - Львів: Видавництво Львівської політехніки, 2013. - 500 с.

9. Пістунов I. М. Інформаційні системи в фінансово-кредитних установах [текст] навчальний посібник / I. M. Пістунов, Т. В. Борщ. - К.: «Центр учбової літератури», 2013. - 234 с.

10. Сікірда Ю. В. Інформаційні системи і технології в управлінні зовнішньоекономічною діяльністю : конспект лекцій / Ю. В. Сікірда, А. В. Залевський. - Кіровоград : Видавництво КЛА НАУ, 2013. - 177 с.

11. Федотова Е.Л. Информационные технологии и системы: учеб. пособие / Е.Л. Федотова. - М.: ИД “ФОРУМ”: ИНФРА-М, 2014. - $352 \mathrm{c.}$

12. Шило С. Г. Інформаційні системи та технології : навчальний посібник / С. Г. Шило, Г. В. Щербак, К. В. Огурцова. - Х. : Вид. ХНЕУ, 2013. - 220 с.

\section{References}

1. Anisimov A.V. Informatsiini systemy ta bazy danykh: Navchalnyi posibnyk dlia studentiv fakultetu kompiuternykh nauk ta kibernetyky. / Anisimov A.V., Kuliabko P.P. - Kyiv. - 2017. - 110 s.

2. Antonenko V. M. Suchasni informatsiini systemy i tekhnolohii: upravlinnia znanniamy : navch. posibnyk / V. M. Antonenko, S. D. Mamchenko, Yu. V. Rohushyna. - Irpin : Nats. universytet DPS Ukrainy, 2016. - 212 s. 2014. $-238 \mathrm{~s}$

3. Informatsiini systemy v promyslovosti : navchalnyi posibnyk / L. O. Dobrovolska, O. O. Cherevko. - Mariupol : PDTU,

4. Kalinesku T.V. Informatsiini systemy i tekhnolohii v opodatkuvanni: navch. posib. / T.V. Kalinesku, H.S. Likhonosova, O.M. Antipov. - Luhansk: vyd-vo SNU im. V. Dalia, 2011. - 407 s.

5. Klimushyn P. S. Informatsiini systemy ta tekhnolohii v ekonomitsi : navch. posib. / P. S.Klimushyn, O.V. Orlov, A.O. Serenok. — Kh. : Vyd-vo KharRI NADU «Mahistr», 2011. - 448 s.

6. Kostrikov S. V. Heohrafichni informatsiini systemy: navchalno-metodychnyi posibnyk. / Kostrikov S. V., Sehida K. Yu. - Kharkiv, $2016-82 \mathrm{~s}$.

7. Morze N.V. Informatsiini systemy. Navch. posibn. /za nauk. red. N. V. Morze; Morze N.V., Pikh O.Z. - Ivano-Frankivsk, «ileiaNV», - 2015. - $384 \mathrm{~s}$.

8. Pavlysh V. A. Osnovy informatsiinykh tekhnolohii i system: Navchalnyi posibnyk. / Pavlysh V. A., Hlinenko L. K. Lviv: Vydavnytstvo Lvivskoi politekhniky, 2013. - $500 \mathrm{~s}$.

9. Pistunov I. M. Informatsiini systemy v finansovo-kredytnykh ustanovakh [tekst] navchalnyi posibnyk / I. M. Pistunov, T. V. Borshch. - K.: «Tsentr uchbovoi literatury», 2013. - $234 \mathrm{~s}$.

10. Sikirda Yu. V. Informatsiini systemy i tekhnolohii v upravlinni zovnishnoekonomichnoiu diialnistiu : konspekt lektsii / Yu. V. Sikirda, A. V. Zalevskyi. - Kirovohrad : Vydavnytstvo KLA NAU, 2013. - 177 s.

11. Fedotova E.L. Ynformatsyonnue tekhnolohyy y systemu: ucheb. posobye / E.L. Fedotova. - M.: YD "FORUM": YNFRA-M, 2014. - $352 \mathrm{~s}$.

12. Shylo S. H. Informatsiini systemy ta tekhnolohii : navchalnyi posibnyk / S. H. Shylo, H. V. Shcherbak, K. V. Ohurtsova. - Kh. : Vyd. KhNEU, 2013. - 220 s. 